\title{
PLANKTON ANALYSIS IN THE PONDS OF CATFISH (Clarias sp.) AND NILE TILAPIA (Oreochromis niloticus)
}

\author{
Diana Arfiatia,*, Zakiyyah Nur Inayaha, Shofiyatul Lailiyah ${ }^{\mathrm{a}}$ and Karina Farkha Dina $^{\mathrm{a}}$

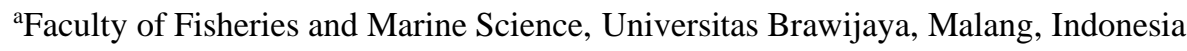 \\ *Corresponding author : d-arfiati@ub.ac.id
}

\begin{abstract}
Catfish and Nile tilapia ponds contain high organic matter levels which will be decomposed by bacteria. It also produces carbon dioxide, which can be utilized by phytoplankton for photosynthesis process. This research aimed to compare the types of phytoplankton and zooplankton in Clarias and Nila tilapia ponds for eutrophication and water quality control. The research was conducted in August-September 2020. The water samples were taken using plankton net to become $35 \mathrm{ml}$ from Clarias and Nile tilapia ponds. Analysis of plankton abudance, diversity, Evenness and Dominance Index was carried out in the Laboratorium Hidrobiologi. The analysis result of the average abundance of phytoplankton in the Clarias ponds was 71.026 cell/mL (11 genera), and zooplankton was $93 \mathrm{ind} / \mathrm{mL}$ (4 genera). Meanwhile in Nile tilapia ponds was 1.503 cell/mL ( 9 genera), and zooplankton was $91 \mathrm{ind} / \mathrm{mL}$ ( 1 genus). The average of zooplankton in Nile tilapia pond was higher than in catfish ponds; since Clarias are carnivores while Tilapia are omnivores. The plankton diversity index of catfish pond was average 0.817 , while in Nile Tilapia was average 0.553 . The evenness ndex of catfish pond was average 0.5 , while in Nile Tilapia was average 0,4 . The dominance index of catfish pond was average 0.59 , while in Nile Tilapia was average 0.77 . The conclusion is that the percentage of phytoplankton in catfish ponds is $99.62 \%$ and zooplankton is $0.38 \%$, while in tilapia the percentage of phytoplankton is $97.85 \%$ and zooplankton is $2.15 \%$.
\end{abstract}

Keywords: Clarias, Diversity Index, Dominance Index, Nile tilapia, Plankton, Evenness Index

\begin{abstract}
Abstrak
Kolam budidaya ikan lele dan nila memiliki kandungan bahan organik tinggi yang akan diuraikan oleh bakteri. Bakteri akan menghasilkan karbondioksida, yang dapat dimanfaatkan oleh fitoplankton untuk proses fotosintesis. Penelitian ini bertujuan untuk membandingkan jenis fitoplankton dan zooplankton di kolam ikan Lele dan Nila untuk eutrofikasi dan pengendalian kualitas air. Penelitian dilakukan pada bulan AgustusSeptember 2020. Pengambilan sampel air menggunakan jaring plankton menjadi 35 ml dari kolam ikan lele dan nila. Analisis kelimpahan, keanekaragaman, keseragaman dan indeks dominasi plankton dilakukan di Laboratorium Hidrobiologi. Hasil analisis kelimpahan rata-rata fitoplankton di kolam Ikan lele adalah 71.026 sel / mL (11 genera), dan zooplankton 93 ind / mL (4 genera). Sedangkan di kolam nila sebesar 1,503 sel / $\mathrm{mL}$ (9 genera) dan zooplankton 91 ind / mL (1 genus). Rata-rata zooplankton di kolam nila lebih tinggi dari pada kolam lele, karena Ikan lele adalah karnivora sedangkan Nila adalah omnivora. Indeks keanekaragaman plankton pada kolam lele rata-rata 0,817 sedangkan pada kolam ikan nila rata-rata 0,553 . Keseragaman kolam lele rata-rata 0,5, sedangkan kolam ikan nila rata-rata 0,4. Indeks dominasi kolam lele rata-rata 0,59, sedangkan pada kolam ikan nila rata-rata 0,77. Kesimpulannya adalah persentase fitoplankton pada kolam ikan lele $99,62 \%$ dan zooplankton 0,38\%, sedangkan pada kolam ikan nila persentase fitoplankton 97,85\% dan zooplankton $2,15 \%$.
\end{abstract}

Kata kunci: Clarias, Indeks Keanekaragaman, Indeks Dominasi, Nila tilapia, Plankton, Indeks Kemerataan

\section{INTRODUCTION}

Plankton are small organisms that live floating in water columns and are important components in aquatic ecosystems. Phytoplankton is a plankton capable of photosynthesis and acts as a producer in aquatic ecosystems. Zooplankton is plankton 
which acts as the first consumer that connects phytoplankton with producers with organisms higher up the food chain. Zooplankton acts as a bioindicator of changing environmental conditions. The richness and abundance of phytoplankton and zooplankton in waters illustrates the fertility of the waters [1].

Plankton has an important role in the aquatic ecosystem, especially phytoplankton. The ability of phytoplankton to convert nutrients into dissolved oxygen which is needed by all aquatic organisms [2]. Cultivation of catfish and tilapia has high levels of organic matter from uneaten feed residue and fish feces. In the Catfish pond, the total organic matter content was $73.31 \mathrm{mg} / \mathrm{L}$, while in the Tilapia pond the total organic matter was $51.48 \mathrm{mg} / \mathrm{L}$. The total organic matter content in the waters of more than 26 $\mathrm{mg} / \mathrm{L}$ is classified as high [3],[4]. Giving artificial feed to the cultivation pond will increase the content of organic matter and water nutrients [5]. The organic material will then be decomposed by bacteria in the waters to produce a product in the form of carbon dioxide and water. The carbon dioxide will then be used by phytoplankton in the photosynthesis process to become oxygen [6].

A water that changes the color of the water can be caused by the presence of other materials such as minerals, organisms that live in water, extracts of organic compounds and plants. Changes occur due to the environment, weather and other materials in the water [7]. This research aimed to compare the types of phytoplankton and zooplankton in Clarias and Nile tilapia ponds.

\section{METHOD}

\section{Research Time and Location}

The research was conducted in August September 2020. Water samples were taken from the Catfish ponds and Nile Tilapia ponds at the Instalasi Budidaya Perikanan, Kepanjen, Malang. Identification, observation of plankton and measurement of water quality in the Laboratorium Hidrobiologi, Divisi Sumberdaya Ikan, Faculty of Fisheries and Marine Sciences, Universitas Brawijaya, Malang. The physical and chemical quality of water measured were temperature, $\mathrm{pH}$, dissolved oxygen and total organic matter.

\section{Water Sampling}

Water samples for plankton identification were taken from Catfish and Tilapia ponds. Water samples were taken using a bucket volume of 35 liters and filtered using a 25 micron mesh size plankton net. Before taking water samples, a $35 \mathrm{ml}$ plankton bottle was tied to the tapered end of the plankton net. Furthermore, 10 liters of sample water was taken with a bucket and filtered with 25 micron mesh size plankton for 3 times. Sample water is taken from the inlet, center and outlet of the pond. The pankton bottle is then taken from the plankton net with care so that the sample water does not spill. The water sample was then given $1 \mathrm{ml}$ of lugol solution and labeled the plankton bottle. Rinse the plankton net with clean water, then use it again to take water samples from other ponds.

\section{The Abundance Index of Plankton}

The calculation of plankton abundance can be done using the following formula [8]:

$$
\mathrm{N}=\frac{O i}{O p} \times \frac{V r}{V o} \times \frac{1}{V s} \times \frac{n}{p}
$$

\section{Information:}

$\mathrm{N}$ = Number of individuals per liter (ind/ $\mathrm{ml}$ ),

$\mathrm{Oi}=$ Area of the cover glass,

$\mathrm{Op}=$ Area of one field of view,

$\mathrm{Vr}=$ Volume of water filtered,

$\mathrm{Vo}=$ The volume of one drop of water sample,

$\mathrm{Vs}=$ The volume of water filtered by the plankton net,

$\mathrm{N}=$ The amount of plankton in the entire field of view,

$\mathrm{P}=$ The number of fields of view observed.

\section{The Diversity Index of Plankton}

Diversity index is used to determine the diversity of plankton species in Catfish and Nile Tilapia aquaculture ponds. The calculation of the diversity index uses the Shannon-Wiener equation with the following formula [9]:

$$
\mathrm{H}^{\prime}=-\sum \mathrm{Pi} \ln \mathrm{Pi}
$$

Information:

$\mathrm{H}^{\prime}=$ Shannon-Wiener diversity index

$\mathrm{Pi}=\mathrm{ni} / \mathrm{N}$

$\mathrm{ni}=$ number of individuals of type $\mathrm{i}$ 
$\mathrm{N}=$ total number of individuals

Criteria:

$\mathrm{H}^{\prime}<1 \quad=$ low diversity

$1<\mathrm{H}^{\prime}<3=$ moderate diversity

$\mathrm{H}^{\prime}>3=$ high diversity

\section{The Evenness Index of Plankton}

The evenness index is used to determine the distribution pattern of plankton evenly or not. If the evenness index value is high, it means that the plankton in the waters is in even condition. The evenness index can use the following formula [10]:

$$
E=\frac{H^{\prime}}{H^{\prime} \max }
$$

Information:

$$
\begin{array}{ll}
\mathrm{E} & =\text { Evenness index } \\
\mathrm{H}^{\prime} & =\text { Lean diversity index } \\
\mathrm{H}^{\prime} \max & =\ln \mathrm{S} \\
\mathrm{S} & =\text { Number of species found }
\end{array}
$$

\section{The Dominance Index of Plankton}

The dominance index is used to determine the presence of certain dominance in certain waters. The calculation of the domination index can use the following formula [11]:

$$
C=\sum_{i=1}^{n}\left(\frac{n i}{N}\right)^{2}
$$

Information:

$\mathrm{C}=$ Domination Index

$\mathrm{Ni}=$ Number of individuals of type $\mathrm{i}$

$\mathrm{N}=$ Total number of individuals

\section{RESULT AND DISCUSSION}

The results of the analysis of plankton identification in general, the abundance of phytoplankton is more than the abundance of zooplankton. The abundance of plankton in Catfish pond was dominated by phytoplankton as much as $99.62 \%$ with an average abundance of phytoplankton 71,026 cells / ml and zooplankton as much as $0.38 \%$ with an average abundance of 93 ind / $\mathrm{ml}$. Percentage phytoplankton divion in Catfish pond; the division of Bacillariophyta $5 \%$, Charophyta 47\%, Chlorophyta 40\% and Cyanophyta 9\%, while zooplankton division Ciliata $0.25 \%$ and Rotifera $0.14 \%$. The abundance of plankton in Nile Tilapia pond was dominated by phytoplankton as much as $97.85 \%$ with an average abundance of phytoplankton 1,503 cells / $\mathrm{ml}$ and zooplankton as much as $0.38 \%$ with an average abundance of 91 ind $/ \mathrm{ml}$. Percentage phytoplankton division in Nile Tilapia pond; the division of Bacillariophyta was $6 \%$, Charophyta $64 \%$, Chlorophyta $28 \%$ and Cyanophyta $0 \%$, while the zooplankton division of Ciliata was $0 \%$ and Rotifera was $2.15 \%$. The results of the calculation of phytoplankton abundance can be seen in Table 1 and the abundance of zooplankton can be seen in Table 2.

In general, phytoplankton in Catfish and Nile Tilapia ponds were more than zooplankton, but in Nile Tilapia the abundance of phytoplankton was lower. This is because Nile Tilapia are omnivores (eat phytoplankton and zooplankton), while catfish are carnivores (eat zooplankton). The phytoplankton in catfish ponds were also found in thes genera Nitzchia, Synedra, Pediastrum, Scenedesmus and Gleocapsa, zooplankton which were also found in Brachionus [12]. Catfish ponds contain zooplankton from the genus Brachionus [13]. The phytoplankton genus Nitzschia, Gonium, Pediastrum, Scenedesmus, Gloeocapsa and Zooplankton from the genus Brachionus were also found in Nile Tilapia ponds [14], [15].

The types of phytoplankton from the Bacillariophyta and Chlorophyta divisions are found in many Indonesian waters [16]. Phytoplankton from the Bacillariophyta, Charophyta and Chlorophyta divisions are found mostly in catfish and tilapia ponds, presumably because these waters have water conditions suitable for their growth, which is related to the presence of nutrients in the waters [17]. Phytoplankton from the Cyanophyta division are mostly found in freshwater because they have a high temperature tolerance in the temperature range of $20^{\circ} \mathrm{C}-30^{\circ} \mathrm{C}$ [18]. Zooplankton from the Rofitera division are often used as natural food for fish. The low abundance of rotirefa is due to the presence of carnivorous and omnivore fish that use zooplankton as their food source [19], [20]. Zooplankton from the Ciliate division are widely used to indicate pollution in a waters [21]. 
Table 1. The Abundance of Phytoplankton in Catfish and Nile Tilapia Ponds (Cell/ ml)

\begin{tabular}{|c|c|c|c|c|}
\hline \multirow{2}{*}{ No } & \multirow{2}{*}{ Division } & \multirow{2}{*}{ Genus } & \multicolumn{2}{|c|}{ Pond } \\
\hline & & & Catfiah & Nile Tilapia \\
\hline 1 & Bacillariophyta & Nitzchia & 7124 & 706 \\
\hline 2 & Bacillariophyta & Synedra & 16471 & 252 \\
\hline 3 & Charophyta & Hyalotheca & 612739 & 10739 \\
\hline 4 & Charophyta & Spirogyra & 777 & 0 \\
\hline 5 & Chlorophyta & Actinastrum & 1246 & 202 \\
\hline 6 & Chlorophyta & Ankistrodesmus & 212 & 0 \\
\hline 7 & Chlorophyta & Golenkinia & 983 & 20 \\
\hline & Chlorophyta & Gonium & 117536 & 2844 \\
\hline & Chlorophyta & Pediastrum & 11480 & 323 \\
\hline & Chlorophyta & Scenedesmus & 8642 & 1392 \\
\hline & Cyanophyta & Gloeocapsa & 4079 & 61 \\
\hline \multicolumn{3}{|c|}{ Total } & 781288 & 16538 \\
\hline \multicolumn{3}{|c|}{ Average } & 71026 & 1503 \\
\hline
\end{tabular}

Table 2. The Abundance of Zooplankton in Catfish and Nile Tilapia Ponds (ind / ml)

\begin{tabular}{|c|c|c|c|c|}
\hline \multirow{2}{*}{ No } & \multirow{2}{*}{ Division } & \multirow{2}{*}{ Genus } & \multicolumn{2}{|c|}{ Pond } \\
\hline & & & Catfiah & Nile Tilapia \\
\hline 1 & Ciliata & Epistylis & 0 & 0 \\
\hline 2 & Ciliata & Frontonia & 222 & 0 \\
\hline 3 & Rotifera & Brachionus & 50 & 363 \\
\hline \multirow[t]{3}{*}{4} & Rotifera & Rotaria & 70 & 0 \\
\hline & & & 373 & 363 \\
\hline & & & 93 & 91 \\
\hline
\end{tabular}

Tabel 2. Diversity Index (H'), Evenness Index (E), and Dominance Index (C)

\begin{tabular}{ccccccc}
\hline \multirow{2}{*}{ Pond } & \multicolumn{3}{c}{ Phytoplankton } & \multicolumn{3}{c}{ Zooplankton } \\
\cline { 2 - 7 } & H' $^{\prime}$ & $\mathbf{E}$ & $\mathbf{C}$ & H'$^{\prime}$ & $\mathbf{E}$ & $\mathbf{C}$ \\
\hline Catfish & 1.084 & 0.525 & 0.501 & 0.550 & 0.500 & 0.671 \\
Nile Tilapia & 1.106 & 0.896 & 0.531 & 0 & 0 & 1 \\
\hline
\end{tabular}

The phytoplankton diversity index in Catfish and Nile Tilapia ponds shows moderate diversity, while the zooplankton diversity index is low. The phytoplankton and zooplankton evenness index in Catfish ponds has moderate evenness. The phytoplankton evenness index of Nile Tilapia ponds has high evenness, while zooplankton has low evenness. The dominance index of phytoplankton and zooplankton in catfish ponds has moderate dominance. The dominance index of Nile Tilapia phytoplankton has moderate dominance, while zooplankton has high dominance. The results of the calculation of the diversity index, evenness index and dominance index can be seen in Table 3.

The average abundance of phytoplankton in goldfish ponds in IBAT Punten, Batu, East Java was 1538 cells / $\mathrm{ml}$, while in tilapia fish ponds were 4900 cells / $\mathrm{ml}$. The dominance index of phytoplankton in goldfish ponds was 0.128 and tilapia ponds were 0.153 . The relative abundance of phytoplankton in goldfish ponds consisted of 51\% Chrysophyta, $36 \%$ Chlorophyta, 12\% Cyanophyta, and 1\% Cryptophyta, while tilapia ponds consisted of 40\% Cyanophyta, 33\% Chrysophyta, and 27\% Chlorophyta. The Evenness Index (E) in the goldfish pond was 0.98 and in the Tilapia pond was 0.86 . The abundance of phytoplankton is higher in gold ponds compared to tilapia, presumably because carp generally prefer to consume phytoplankton than tilapia. Although the appearance of tilapia does not like consuming phytoplankton, phytoplankton has a strong correlation with the growth of tilapia [22].

The results of the measurement of water quality in the Catfish and Nile Tilapia ponds showed that it has an optimum range for aquatic organisms. The results of measuring the quality of Catfish and Tilapia aquaculture ponds can be seen in Table 4. The temperature level in the catfish pond averaged $27^{\circ} \mathrm{C}$, while in the tilapia pond the average was $27.40{ }^{\circ} \mathrm{C}$. 
The optimum temperature for organisms in the daily cultivation system ranges from $22^{\circ} \mathrm{C}-30$ ${ }^{\circ} \mathrm{C}[23]$.

The average $\mathrm{pH}$ level in the Catfish pond is around 7, while in the Tilapia pond it is around 8. A water that has a $\mathrm{pH}$ range of $6-9$ is good water for the life of aquatic organisms [24]. Dissolved oxygen levels in the catfish pond averaged $5.4 \mathrm{mg} / \mathrm{L}$, while in the Tilapia pond the average was $4.57 \mathrm{mg} / \mathrm{L}$. The optimum dissolved oxygen value for aquatic life in both aquaculture and public waters is $>4$ $\mathrm{mg} / \mathrm{L}$. [25].

The total organic matter content in the catfish pond averaged $36.66 \mathrm{mg} / \mathrm{L}$, while in the tilapia pond the average was $28.15 \mathrm{mg} / \mathrm{L}$. Waters that contain more than $26 \mathrm{mg} / \mathrm{L}$ of organic matter are considered high. Sources of organic matter in water can come from the metabolism of organisms and the phytoplankton production process [26]. The presence of organic matter in water can be in the form of suspended and dissolved organic matter, as well as organic material in the form of plankton and other organisms [27].

Table 4. Results of Measurement of Water Quality in Catfish and Tilapia Cultivation Ponds

\begin{tabular}{clcc}
\hline No & Parameter & $\begin{array}{c}\text { Catfish } \\
\text { Pond }\end{array}$ & $\begin{array}{c}\text { Nile Tilapia } \\
\text { Pond }\end{array}$ \\
\hline 1 & Suhu $\left({ }^{\circ} \mathrm{C}\right)$ & 27,8 & 27,40 \\
2 & pH & 7 & 8 \\
3 & DO $(\mathrm{mg} / \mathrm{L})$ & 5,4 & 4,57 \\
4 & TOM $(\mathrm{mg} / \mathrm{L})$ & 36,66 & 28,15 \\
\hline
\end{tabular}

\section{CONCLUSION}

The conclusion was obtained that the types of phytoplankton in Catfish pond consisted of 11 genera (Nitzchia, Synedra, Hyalotheca, Spyrogyra, Actinastrum, Ankistrodesmus, Golenkinia, Gonium, Pediastrum, Scenedesmus and Gloeocapsa) and 4 genera zooplankton (Epistylis, Frontonia, Brachionus and Rotaseia) with a percentage of phytoplankton $99.62 \%$ and zooplankton $0.38 \%$, while in Tilapia the types of phytoplankton consisted of 9 genera (Nitzchia, Synedra, Hyalotheca, Actinastrum, Golenkinia, Gonium, Pediastrum, Scenedesmus and Gloeocapsa) and zooplankton 1 genus (Brachionus) with a percentage of phytoplankton $97.85 \%$ and zooplankton $2.15 \%$.

\section{REFERENCES}

[1] M. Hidayat, "Keanekaragaman plankton di Waduk Keuliling Kecamatan Kuta Cot Glie Kabupaten Aceh Besar," $J$. Biot., vol. 1, no. 2, pp. 67-72, 2013.

[2] M. S. Usman, J. D. Kusen, and J. R. T. S. L. Rimper, "Struktur komunitas plankton Di Perairan Pulau Bangka Kabupaten Minahasa Utara," J. Pesisir Dan Laut Trop., vol. 1, no. 2, p. 51, 2013, doi: 10.35800/jplt.1.2.2013.2149.

[3] D. Arfiati, K. F. Dina, S. Lailiyah, E. Adialam, and N. Cokrowati, "Effectiveness of bacterial attachment media to reduce organic matter from wastewater of catfish aquaculture," in IOP Conference Series: Earth and Environmental Science, 2020, vol. 493, no. $1, \quad$ doi: $10.1088 / 1755-$ 1315/493/1/012001.

[4] A. Athirah, A. Mustafa, and M. A. Rimmer, "Perubahan kualitas air pada budidaya ikan Nila (Oreochromis niloticus) di Tambak Kabupaten Pangkep Provinsi Sulawesi Selatan," in Prosiding Forum Inovasi Teknologi Akuakultur, 2013, vol. 1, no. 1, pp. 1065-1075.

[5] H. Andriyani, E. Widyastuti, and D. S. Widyartini, "Kelimpahan Chlorophyta pada media budidaya ikan Nila yang diberi pakan fermentasi dengan penambahan tepung kulit ubi kayu dan probiotik," Scr. Biol., vol. 1, no. 1, p. 51, 2014, doi: 10.20884/1.sb.2014.1.1.26.

[6] M. R. Firdaus and L. A. S. Wijayanti, "Fitoplankton dan siklus karbon global," Oseana, vol. 44, no. 2, pp. 35-48, 2019, doi:

10.14203/oseana.2019.vol.44no.2.39.

[7] M. Pramleonita, N. Yuliani, R. Arizal, and S. E. Wardoyo, "Parameter fisika dan kimia air kolam ikan Nila Hitam (Oreochromis niloticus)," J. Sains Nat. Univ. Nusa Bangsa, vol. 8, no. 1, pp. 2434, 2018.

[8] F. Sarinda, I. Dewiyanti, and B. Metode, 
"Keragaman fitoplankton di perairan estuaria Kuala Gigieng Kabupaten Aceh Besar, Provinsi Aceh," Depik, vol. 2, no. 1, pp. 20-25, 2013, doi: 10.13170/depik.2.1.581.

[9] S. Hutabarat, P. Soedarsono, and I. Cahyaningtyas, "Studi analisa plankton untuk sungai Babon Semarang," $J$. Manag. Aquat. Resour., vol. 2, no. 3, pp. 74-84, 2013.

[10] K. Paiki, J. D. Kalor, E. Indrayani, and L. Dimara, "Distribusi Kelimpahan dan keanekaragaman zooplankton di perairan pesisir Yapen Timur , Papua," Maspari J., vol. 10, no. 2, pp. 199-206, 2018.

[11] A. Nurruhwati, Isni; Zahidah; Sahidin, "Kelimpahan plankton di Waduk Cirata Provinsi Jawa Barat," J. Akuatika Indones., vol. 2, no. 2, pp. 102-108, 2017.

[12] D. Nafila, R. Rustadi, and D. Djumanto, "Preferences of Giant Gouramy (Osphronemus gouramy, Lac, 1801.), Walking Catfish (Clarias sp.) and Red Nile (Oreochromis sp.) on natural feed in fish culture," J. Perikan. Univ. Gadjah Mada, vol. 20, no. 2, p. 63, 2019, doi: $10.22146 /$ jfs.34494.

[13] A. Adedeji, I. Adeniyi, and H. Masundire, "Zooplankton abundance and diversity of fishponds exposed to different management practices," Int. J. Biol. Chem. Sci., vol. 7, no. 2, 2013, doi: 10.4314/ijbcs.v7i2.19.

[14] A. T. Reyes, A. C. Ramos, and J. O. Saturno, "Phytoplankton abundance, diversity, evenness and composition in tilapia ponds fertilized with chicken manure and organic fertilizer," Int. J. Bot. Stud., vol. 4, no. 3, pp. 72-76, 2019.

[15] A. N. A. F. Ibrahim, M. S. M. Castilho Noll, and W. C. Valenti, "Zooplankton capturing by nile tilapia, Oreochromis niloticus (Teleostei: Cichlidae) throughout post-larval development," Zoologia, vol. 32, no. 6, pp. 469-475, 2015, doi: $10.1590 /$ S1984-

\section{6.}

[16] F. Sulawesty dan Tri Suryono, "Komunitas fitoplankton kaitannya dengan kualitas perairan Danau Sentani," Limnotek, vol. 23, no. 2, pp. 61-74, 2017.

[17] T. Apriadi and I. H. Ashari, "Struktur Komunitas Fitoplankton pada kolong pengendapan limbah tailing," Maj. Ilm. Biol. Biosf. A Sci. J., vol. 35, no. 3, pp. 145-152, 2018, doi: 10.20884/1.mib.2018.35.3.761.

[18] N. Q. A'ayun, T. A. P. Perdana, P. A. Pramono, and A. N. Laily, "Identifikasi fitoplankton di perairan yang tercemar lumpur lapindo, Porong Sidoarjo," Bioedukasi J. Pendidik. Biol., vol. 8, no. 1, p. 48, 2015, doi: 10.20961/bioedukasiuns.v8i1.3414.

[19] E. Roziaty, D. H. Aksiwi, and N. A. D. Setyowati, "Keragaman plankton di wilayah perairan Waduk Cengklik Boyolali Jawa Tengah," Bioeksperimen J. Penelit. Biol., vol. 4, no. 1, pp. 69-77, 2018, doi: 10.23917/bioeksperimen.v4i1.5935.

[20] H. Pradana, M. S. F., Hasan, Z., Nurruhwati, I., dan Herawati, "Struktur komunitas plankton di Cekdam Kampus Universitas Padjadjaran," J. Perikan. dan Kelaut., vol. 10, no. 2, pp. 1-8, 2019.

[21] K. Amri, A. Ma'mun, A. Priatna, A. Suman, E. Prianto, and Muchlizar, "sebaran spasial, kelimpahan dan struktur komunitas zooplankton di estuari sungai Siak serta faktor-faktor yang mempengaruhinya," J. Akuatika Indones., vol. 5, no. 1, pp. 7-20, 2020.

[22] D. Arfiati, P. Purwanti, S. Permanasari, and A. W. Puspitasari, "Analysis of phytoplankton on The Common Carp (Cyprinus carpio) Pond and Tilapia (Oreochromis niloticus) Pond at IBAT Punten, Batu, East Java," El-Hayah, vol. 7, no. 1, pp. 12-20, 2019, doi: 10.18860/elha.v7i1.7242.

[23] Muarif, "Karakteristik Suhu Perairan di 
Kolam Budidaya Perikanan," Jurna Mina Sains, vol. 2, no. 2, pp. 96-101, 2016.

[24] H. Pranoto, "Studi Kelimpahan dan keanekaragaman makrozoobentos di perairan Bedagai, Kecamatan Tanjung Beringin Kabupaten Serdang Bedagai," J. Biosains, vol. 3, no. 3, p. 125, 2017, doi: 10.24114/jbio.v3i3.8107.

[25] O. Lepa, S. Kulla, E. Yuliana, and E. Supriyono, "Analisis kualitas air dan kualitas lingkungan untuk budidaya ikan di Danau Laimadat, Nusa Tenggara Timur," PelagicusJurnal IPTEK Terap. Perikan. dan Kelaut., vol. 1, no. 3, pp. 135-144, 2020.
[26] D. I. Santi, N. Afiati, and P. W. Purnomo, "Sebaran bakteri heterotrof, bahan organik total, nitrat dan klorofil-a air muara sungai Cipasauran, Serang," $J$. Maquares, vol. 6, no. 3, pp. 222-229, 2017.

[27] I. S. Djunaidah, L. Supenti, D. Sudinno, and H. Suhrawardan, "Kondisi perairan dan struktur komunitas plankton di Waduk Jatigede," Jurna Penyul. Perikan. dan Kelaut., vol. 11, no. 2, pp. 79-93, 2017. 